This is a self-archived - parallel published version of this article in the publication archive of the University of Vaasa. It might differ from the original.

\title{
Entrepreneurial discovery processes, knowledge creation and knowledge space
}

Author(s): Virkkala, Seija

Title: $\quad$ Entrepreneurial discovery processes, knowledge creation and knowledge space

Year: $\quad 2019$

Version: Accepted manuscript

Copyright (C) 2019 Routledge. Selection and editorial matter, Åge Mariussen, Seija Virkkala, Håkon Finne and Tone Merethe Aasen; individual chapters, the contributors. This is an Accepted Manuscript of a book chapter published by Routledge in The Entrepreneurial Discovery Process and Regional Development: New Knowledge Emergence, Conversion and Exploitation on 7 January 2019, available online: https://doi.org/10.4324/9781351273763

Please cite the original version:

Virkkala, S. (2019). Entrepreneurial discovery processes, knowledge creation and knowledge space. In: Mariussen, Å., Virkkala, S., Finne, H. \& Aasen, T. M. (eds.) The Entrepreneurial Discovery Process and Regional Development: New Knowledge Emergence, Conversion and Exploitation, 154-175. Routledge. https://doi.org/10.4324/9781351273763-9 


\title{
8 \\ Entrepreneurial discovery processes, knowledge creation and knowledge space
}

\author{
Seija Virkkala
}

\section{Introduction}

The focus of this book is the transition from exploitation to exploration in an entrepreneurial discovery process (EDP) and the preconditions and implications of that change for entrepreneurial actors, the regional economy and knowledge creation. Whereas Chapter 1 (Virkkala and Mariussen, 2019b) focuses on agency or the 'self' in self-discovery and Chapter 9 (Virkkala and Mariussen, 2019a) on the changes to a regional economy through emergence and through transnational networks, this chapter describes EDP as a process of knowledge creation. Entrepreneurial knowledge is a driver of the discovery process (Foray, 2015:24) both in the phase of searching for new business fields (domains) and in the implementation phase of the smart specialisation strategies (S3). In the discovery process, regional stakeholders should combine various types of knowledge: knowledge of local capabilities and assets of the region; relevant scientific and technological knowledge; knowledge of the competitive market; and knowledge of the organisations and firms providing the required knowledge. In addition, visionary knowledge of the region's future specialisation within the knowledge economy is required. According to Foray (2016) the knowledge needed for discovery is dispersed, fragmented and hidden.

This chapter argues that when knowledge is generated the space for knowledge will also be created. The search for new regional business fields can be seen as a knowledge creation process as well as a process of the creation of knowledge space. In this process, the proximities and distances between the stakeholders, or entrepreneurial actors, are changing and a new balance between proximities and distances will be created. This argument is based on the reasoning of Nonaka and Takeuchi (1995) that learning is knowledge creation and its context is $b a^{\mathrm{i}}$, which is the place where knowledge is created. This chapter aims to contribute to the emerging literature on EDP from the points of view of knowledge creation and knowledge space. The current study distinguishes the space for knowledge from the bounded administrative territory. In the context of regional development policies like S3, regional economies are understood as territorially bounded areas, which must be renewed and transformed due for instance to the challenges of globalisation, digitalisation, ageing and climate change. The knowledge space as the context for knowledge creation is more abstract and flexible. The current chapter examines a research question: how are the knowledge creation process and the construction of the knowledge space connected in the context of the $E D P$ ? This research question will be approached with the help of a framework based on theories of organisational learning and communities as well as geographical theories on space. Knowledge creation in the EDP can be organised in different ways, but the interaction between entrepreneurial actors and the spaces for this interaction are crucial.

When viewing the discovery process as a knowledge creation process, it is important to recognise the role of tacit knowledge. The latent competitive advantage of the region involves 
tacit knowledge that is difficult for formal bodies to discover. It is necessary to introduce theories of knowledge creation with tacit knowledge at their core. The next section presents some of these approaches including the SECI model and knowledge in action or communities in practice, and the chapter then applies these approaches in its explanation of the EDP. The third section approaches the notion of knowledge space with the help of concepts of relational space and dimensions of proximity. The fourth section builds a framework based on the combination of previously presented knowledge creation approaches and notions of knowledge spaces. The framework describes the EDP as an evolutionary process of sensemaking consisting of searching, interacting, interpretation visioning and experimentation with varying features of a knowledge space.

In the fifth section, two examples of knowledge creation and knowledge space are presented: focus group meetings as a part of a connectivity analysis and also the regional development platform method. Both methods connect entrepreneurial actors from different communities of practice like a specific industry, universities and public government. The connectivity analysis identifies gaps in the innovation system and measures them in terms of the difference between the experience and expectations of a relationship. These gaps are the issues to be discussed and bridged in the focus group meetings (Virkkala et al., 2017). The platform seeks to align several actors to boost future regional economic development (Harmaakorpi, 2006). The final section summarises and discusses the framework developed in the chapter.

\section{Approaches to the knowledge creation process in the EDP}

Knowledge is interpreted as justified true belief (Nonaka and Takeuchi, 1995). Academic knowledge, for example, is justified in relation to the epistemic culture. The truth, understood as shared beliefs, results from processes where people justify and substantiate their beliefs within an organisation (Mariussen, 2013). The dialogue on new opportunities in publicprivate alliances in the EDP is an explanatory process in the field of regional culture.

Knowledge created through the EDP is then substantiated through practices and experiments, and by way of future regional development.

To illuminate the EDP as a knowledge generation process it is necessary to examine different approaches to the knowledge process. The EDP as collective knowledge creation can be explained with the help of organisational knowledge creation theories (organisational learning). There are many approaches in organisational studies but the most famous is the SECI model by Nonaka and Takeuchi (1995).

\section{The SECI model}

The SECI model ${ }^{\text {ii }}$ by Nonaka and Takeuchi (1995) describes how organisations create knowledge. It draws a distinction between explicit (codified) and tacit knowledge. Explicit knowledge is expressed in codified form such as texts, whereas tacit knowledge is deeply rooted in individuals' actions and experience, and the latter contains an important cognitive dimension helping individuals to perceive and define their world. For tacit knowledge to be communicated and shared it has to be converted into words that everyone can understand. When this conversion takes place - from tacit to explicit, and back again into tacit - 
organisational knowledge is created (Nonaka and Takeuchi, 1995). The interaction of these two types of knowledge triggers a knowledge conversion process, that is, the SECI process. The four stages of the SECI process form a spiral of knowledge creation, one that unites the creators (individual, group and organisation) with knowledge (tacit and explicit). The knowledge spiral becomes larger in scale as it moves up the ontological levels. When tacit and explicit knowledge interact, the result is an innovation (Nonaka and Takeuchi, 1995; Nonaka et al., 2001). Knowledge creation is a continuous process of interaction between tacit and explicit knowledge.

The knowledge possessed by individuals must be shared and amplified through interaction with others, and $b a$ is a space where such interaction takes place. Therefore, the knowledgecreating process is also a process of creating $b a$, and a new boundary of interaction (Nonaka et al., 2000). Nonaka and Toyama (2003) consider $b a$ to be a time and space which is shared in order to encourage the emerging relationships among individuals and groups, leading to the creation of knowledge.

The SECI model has been criticised for overemphasising the thing-like nature of tacit knowledge. Tsoukas (2003) argues that tacit and explicit knowledge are two sides of the same coin as even the most explicit kind of knowledge rests on tacit knowledge. Tacit knowing is a necessary component of all knowledge and it is inscribed into the artefacts of codified knowledge (Amin and Cohendet, 2004). In addition, tacit knowing is unintended knowing in action and as such exists only on relation to the focused aspect and cannot be separated from that to be examined independently (Vissers and Dankbaar, 2013). Tacitness is a matter of degree, and in between explicit skills which can easily be communicated and tacit skills which are deeply ingrained and not even accessible to the knowledge holders themselves, there is a group of skills that have not yet been articulated, but that could be if people were asked to do so, and there is also a group of tacit skills that can be accessed through pictures and symbols rather than through language (Virkkala and Mariussen, 2013).

\section{Knowing as action and communities of practice}

The approach of knowledge in practice emphasises that what is known is not a thing or a static property; instead it should be seen as the ability to act. Knowing is our action. Knowledge does not exist independently of social actors and practical contexts. Knowledge should instead be conceived of as embodied and contextually situated in time and space. Knowledge only becomes meaningful in relation to a distinct social practice (Lave and Wenger, 1991). Knowing constitutes action in itself and in purposeful intervention. The practice view, that is, the embeddedness of knowledge in practice, stresses the collective nature of knowing. The dichotomy between tacit knowing and codified knowledge does not make any sense from this theoretical perspective. Knowing is an ongoing social activity, constituted in everyday practice (Orlikowski, 2002). Practical understanding refers to knowing how to carry out a specific activity, what it makes sense to do, and being able to put into practice competently (Lave and Wenger, 1991). Knowledge cannot be transferred but it has to be translated when used under different local and historical conditions (see Chapter 5, (Lam, 2019)). While quanta of knowledge can be exchanged between actors, the essence of distinct practice has to be translated across cultural boundaries (Ibert, 2007). 
The knowledge creation process is difficult because knowledge is embodied in actors and in their practices. Combining knowledge requires common frameworks and understandings.

Entrepreneurial actors in the EDP often represent different communities of practice, implying that knowledge is embodied in them and their practices. The community is an active entity of knowing (Lave and Wenger, 1991). From this perspective, the borders of knowledge practices are important and the creation of the knowledge space representing many communities of practice should focus on the borders and how to transcend the boundaries of practices. In order to create knowledge for discovery, entrepreneurial actors should interact. Such interaction can range from participation in focus groups and workshops to broader community meetings and surveys. It is also possible that during the EDP, a regional community of practice will emerge when a collective agency forms to pursue a discovery process (see Chapter 1 (Virkkala and Mariussen, 2019b)).

\section{Knowledge as object and knowledge as an activity in the EDP}

Vissers and Dankbaar (2013) and Amin and Cohendet (2004) distinguish two different knowledge approaches: knowledge as an asset or object and knowledge as action, that is, social and embodied practice (knowing). Existing research places more emphasis on the view that knowledge is conceived as an activity and process. The notion of knowledge as action implies a constructionist approach according to which knowledge is conceived as a practice created in interaction, and knowledge is inseparable from the person holding that knowledge (Amin and Cohendet, 2004).

It is possible to analyse the EDP by way of two different approaches to the knowledge process: knowledge as an object, based on the content perspective, and knowledge as action based on the relational perspective emphasising the agents and their relations like the theory of communities of practice (Wenger, 1998). Although the SECI model has been criticised for treating knowledge in the manner of a thing, it does have the character of the community of practice and can be seen as linking the two contrasting approaches. It is suggested in the current work that both the SECI model and the knowledge as action or knowing approach can be applied in interpreting the EDP as a process of knowledge generation.

Table 8.1 Two perspectives on knowledge creation

\begin{tabular}{|c|c|c|c|}
\hline & Knowledge-as-object & Knowledge as action & $\begin{array}{l}\text { The EDP as a knowledge } \\
\text { conversion process }\end{array}$ \\
\hline Perspective & Content perspective & $\begin{array}{l}\text { Relational perspective: } \\
\text { knowing agents and the } \\
\text { knowledge context }\end{array}$ & $\begin{array}{l}\text { From content to relational } \\
\text { and collective knowledge }\end{array}$ \\
\hline $\begin{array}{l}\text { Form of } \\
\text { knowledge }\end{array}$ & $\begin{array}{l}\text { Knowledge as an } \\
\text { asset, resource }\end{array}$ & $\begin{array}{l}\text { Knowing, knowledge } \\
\text { activity }\end{array}$ & $\begin{array}{l}\text { From asset to new business } \\
\text { area (domain) }\end{array}$ \\
\hline Method & Follow knowledge & $\begin{array}{l}\text { Follow the knowledge agent: } \\
\text { relations between agents, } \\
\text { what knowledge agents do }\end{array}$ & $\begin{array}{l}\text { Interaction between } \\
\text { entrepreneurial actors is } \\
\text { crucial }\end{array}$ \\
\hline Policy & $\begin{array}{l}\text { Input to knowledge } \\
\text { stock }\end{array}$ & $\begin{array}{l}\text { Creation and support } \\
\text { conditions that foster } \\
\text { interaction }\end{array}$ & Fora for knowledge sharing \\
\hline
\end{tabular}

Sources: based on the ideas of Ibert (2007), Bathelt and Glückler (2011) and Vissers and Dankbaar (2013) 
Entrepreneurial actors search out the elements of a new business field and in that search process their tacit knowledge will be translated according to the knowledge-as-action perspective. This implies changing proximities between the actors. This collective knowledge will become a new relational knowledge which will be one cornerstone of the new business area. However, the tacit knowledge of entrepreneurial actors is also converted to explicit knowledge and combined with the knowledge of local capabilities and general purpose technology (GPT) so that the result will be the knowledge of the new business field. In the EDP, knowledge as an object is transformed into knowledge as a (discovery) process and finally into a knowledge spiral which is a continuous EDP (see Table 8.1).

\section{Knowledge spaces and proximities}

Knowledge processes depend on the spatial contexts, or spaces of knowledge creation. Space and time come together in knowledge creation (Hautala and Jauhiainen, 2014). In order to approach knowledge spaces constructed by the entrepreneurial actors for the discovery, the chapter presents two approaches to space used in geography: relational space, which is in line with networking and the relational economy (Bathelt and Glückler, 2011), as well as places as 'becoming', which is in line with the process thinking and constructivist approaches (Pred, 1984).

Recent geographical literature addresses the cooperation of actors and focuses on relations and networking. The relations and networks between actors or entities can build a space, known as relational space. Relational spaces emerge alongside territorially bounded regions, but they cannot be characterised as discrete geographical units (Cresswell, 2013). They are 'spaces of flows' according to Castells (1998). Relations can move across scales from the local to the global (Massey, 2005). According to the relational approach, objects and their relations create the space. Relational space happens at the same time as the things that are supposed to occur in space. There is no prior existing thing called space, but there are objects and their relations creating the space (Cresswell, 2013; Massey, 2005).

In order to create new knowledge and knowledge space, enough proximity is required to connect actors and to enable interactive learning and innovation. Boschma (2005) suggests five dimensions of proximity, those being: geographical, social, institutional, organisational and cognitive proximity. Geographical proximity promotes unique local competencies, skills and new knowledge, which can diffuse spontaneously through personal contacts via the 'local buzz' (Bathelt et al., 2004). However, geographical proximity alone is not enough to foster knowledge creation, but it can facilitate other forms of proximity and the sharing of tacit knowledge. Social proximity refers to personal relationships between actors; institutional proximity to joint formal and informal rules; organisational proximity to the membership of the same organisational entity; and cognitive proximity to the distance between the knowledge base of actors. To support knowledge creation, there should be optimal cognitive proximity between actors. Social proximity is likely to be more localised than cognitive proximity.

The notion of $b a$ as an arena of knowledge creation by Nonaka and Konno (1998) can be seen as relational space. $B a$ is created through interaction between individuals and with their environment. $B a$ is not necessarily a physical space, but rather a context that harbours 
meaning. It can be physical (office), virtual (email, teleconference), mental (shared experiences, ideas, ideals) or any combination of these. It can be space and time that is shared within a project team, a space for informal dialogue, for sharing experiences with customers, for interdivisional cooperation, or a space shared by virtual companies (Nonaka et al., 2001:18-19). In the EDP context, $b a$ is a space of self-discovery. It can for instance be epitomised in focus group meetings and workshops, in which entrepreneurial actors collectively search for new business fields.

The knowledge space is a dynamic category that is becoming rather than being. The notions of 'becoming' and 'being' in the regional context originate with Pred (1984), who looked upon regions as historically contingent and dynamic categories, which instead of being are constantly becoming. Regions are in a constant state of construction by the agents. Pred applied the ideas of structuration theory to the notion of place. The regions will always be in the process of transformation, and the state of 'becoming' implies a constant balancing of structure and agency. These ideas have been applied in the social construction of the regions via human action and relations between the actors. Regions are social constructs; actors produce and give meaning to them in more or less bounded material and symbolic worlds (Paasi, 2002). Since relations between actors and networks are continuously changing, relational space is in constant process of becoming.

In the context of EDP, knowledge space can have two meanings; first, it is the space in which different knowledge is integrated, and the relations between entrepreneurial actors will be changed as a result of alignment between the entrepreneurial actors (see Chapter 1 by Virkkala and Mariussen (2019b)). In this knowledge space, activities and R\&D measures will be identified which are likely to bring success to a region given its existing capabilities and also the new opportunities for commercially viable lines of business. According to the second interpretation, knowledge space is the result of the discovery of the new business area (=domain) which is the basis for regional S3 (Foray, 2015). The notion of domain can be seen as encapsulating a relational space emerging as a result of changing proximities between the actors. The domain is in the process of 'becoming' when the entrepreneurial actors and other actors implement the regional strategies through experiments. However, the EDP is a continuous exploration since the business opportunities are changing due to the turbulent global environment (Table 8.2).

Knowledge space in the EDP context can be discussed by applying the notions of object space, communicative space and cognitive space (Hautala and Jauhiainen, 2014). Knowledge creation is an interactive process between entrepreneurial actors. An object space is the material environment of an individual, and in the context of the EDP might refer to the facts of the region like its demographic and economic structure. A communicative space is formed as a result of interaction; when people, ideas, information and rituals interact with the communicative space (Amin and Cohendet, 2004). That communicative space refers to networks, epistemic cultures and communities of practice (Wenger, 1998). In this space, people interact and discuss issues through various communication channels. Cognitive space treats knowledge as taking the form of interconnected concepts, theories and ideas: it is what one can analyse, understand and discuss when interpreting interaction. Knowledge is interpreted and substantiated. It comprises mental models of individuals and shared mental models of groups. In a cognitive space, one becomes cognitively closer or more distant. 


\section{EDP as a process of sense-making: Evolution of knowledge creation}

The knowledge conversion process resulting in the discovery of a future specialisation in a region should be embedded in existing local capabilities. The knowledge of entrepreneurial actors should be combined with general purpose technology (GPT) like ICT, nanotechnology or biotechnology aligned with a region's vision ${ }^{\text {iii }}$. The EDP will benefit the existing activities in which the region already specialises (Boschma, 2017). However, many activities cannot be meaningfully combined. Combinations are more likely to emerge from technologies or industries with similar knowledge bases (Frenken et al., 2007; Boschma, 2017). New specialisations emerge from the combination of local capabilities across sectors or technologies, and the result might be novel combinations for the region. The EDP allows room for unexpected connections between unrelated local activities, in that it builds on local activities that have not been connected to date (Boschma, 2017).

The discovery processes should start with a situation in which the actors - for instance in a cluster - utilise and refine the existing regional knowledge base. The relations between the actors are fixed, and this situation is seen as exploitation, which might exhaust the regional knowledge base. New knowledge is needed, and it can be detected by combining existing knowledge or translating the knowledge of entrepreneurial actors, and that outcome demands a new type of knowledge space. It might be a hybrid space in which the agents share and translate their knowledge. The aim is to combine existing knowledge and capabilities in new and perhaps more complex ways. This exploration phase might mean that the proximity between the actors changes, and the result might be more proximate relations between distant actors. This is a largely cognitive dimension of proximity. Knowledge space moves from a fixed structure of exploitation to the new knowledge space in the exploration (see Table 8.2). This new knowledge is an outcome of discovery: it is a new domain that can be exploited to generate new growth in the region. Knowledge space and the exploitation-explorationexploitation phases of EDP are interrelated.

Table 8.2 Knowledge space and time, from exploitation to exploration

\begin{tabular}{|c|c|c|c|}
\hline & Knowledge dynamics & Knowledge space & EDP phase \\
\hline Exploitation & $\begin{array}{l}\text { Cumulative based on } \\
\text { existing knowledge }\end{array}$ & Proximity, fixed relations & $\begin{array}{l}\text { Beginning of discovery } \\
\text { process }\end{array}$ \\
\hline Exploration & $\begin{array}{l}\text { Combinatory knowledge } \\
\text { dynamics }\end{array}$ & $\begin{array}{l}\text { Substitution, new proximity } \\
\text { relations } \\
\text { Hybrid space }\end{array}$ & $\begin{array}{l}\text { Search for new } \\
\text { knowledge discovery }\end{array}$ \\
\hline Exploitation & $\begin{array}{l}\text { Cumulative knowledge } \\
\text { dynamics }\end{array}$ & $\begin{array}{l}\text { New knowledge space: new } \\
\text { balance between proximity and } \\
\text { distance of agents }\end{array}$ & $\begin{array}{l}\text { Result of discovery: } \\
\text { new domain (business } \\
\text { areas): innovation and } \\
\text { growth of the business } \\
\text { area }\end{array}$ \\
\hline
\end{tabular}

Source: Own elaboration

Next, this study explicates the design of the phases of the discovery process from the perspective of creating knowledge and knowledge space. 
At the beginning of the process of discovery, the facilitator should identify and engage with critical entrepreneurial actors who hold knowledge on a region's resources, its strengths, weaknesses and potential. They should have the capacity to engage in exploration and contribute to the EDP. The entrepreneurial actors explore new technological domains and interact with the market. During the discovery, the interaction between the agents and interpretation of knowledge are key. Knowledge gathered, combined and converted during the search process requires interpretation so as to be substantiated and become meaningful. The frame for interpretation is the vision of a region's place in the future knowledge economy. However, interaction and interpretation occur simultaneously in the search process, even if these activities are treated separately in the analysis.

Interacting and searching in the communicative space: Entrepreneurial actors often belong to different communities of practice, but in order to create new knowledge, the knowledge of different practices must be translated. Knowledge sharing often occurs spontaneously between actors, but to facilitate the deliberate search for the transformation of a regional economy, places should be organised to facilitate interaction among actors. There might be borders between different communities and cognitive distance between entrepreneurial actors, but collaboration and structured dialogue is one way of overcoming such cognitive distances. The interaction can occur in different workshops and focus group meetings but also through communication channels in the social media. This space can be seen as a communication space. Interaction can be described as the socialisation phase of the SECI model when the entrepreneurial actors share the same objective of finding new business fields for the regional economy.

Interpretation in the cognitive space: The members of a community of practice might have a similar mental model that helps them to interpret knowledge; for example, the mental models of electrical engineers might diverge from those of marketing specialists or of experts in regional development. The knowledge shared in interaction will be interpreted through mental models of the entrepreneurial actors in the cognitive space. Ideas, concepts, statements, and thoughts arising from interaction are organised into mental models as dynamic and incomplete representations of the world. The mental models of various actors can converge in the cognitive space. The interpretation process occurs both at the individual and group levels. These knowledge bases change and broaden because people learn and correct false combinations through interaction (Weick, 2001). The mental models can be only partly explained, or made explicit, but much of this knowing remains tacit (Nonaka and Takeuchi, 1995; Hautala and Jauhiainen, 2014). Interpretation transforms information into meaningful and applicable knowledge. In the case of the EDP, the mental models connect a vision of the regional development, the local capabilities and potential GPT. Interpretation of knowledge is sense-making and it corresponds to the externalisation phase of the SECI model.

Visioning and new domain: A new domain is the future specialisation of the region which has been found through the processes of searching, interacting and interpreting the knowledge of entrepreneurial actors and combining this new knowledge with a general purpose technology (GPT) like ICT, and with other extra-regional knowledge. It can be seen as the combination phase in the SECI model when the knowledge created by explicated tacit knowledge is combined with the existing codified knowledge. It is based on the shared understanding of the future of the regional economy. The combination of different knowledge affects the proximities between agents. The new domain is also a new knowledge space, in which there is a new balance between proximities and distances between the entrepreneurial actors. Creating 
spaces creates borders to communities of practices. Discovering a new domain might mean that some agents are more important and more central to the new knowledge space and some others more remote from it.

Experimentation and implementation: A new domain informs the whole regional economy of possible new business opportunities. One region can have many new domains, for instance one domain renewing the old industries and another domain creating a new business field based on knowledge spin-offs from universities. The results of discovery will be captured in the smart specialisation strategy encapsulating different priorities. The government should support the activities and projects that appear promising in terms of future innovations and potential for the transformation of the existing structures and that offer economies of scale. A policy should also support the emergence of a micro-system of innovation so that the regional economy might be transformed (Foray, 2016). The implementation and experimentation can be compared with the internalisation phase of the SECI process, when the actors begin to act according to the tangible new knowledge. However, implementation requires reflective learning by trial-and-error as well as a policy environment supporting experimentation. The continuous evaluation of the experiment is crucial, and the new domain as knowledge space is a relational space which is becoming.

\section{Examples from Finland of knowledge spaces in the EDP}

The smart specialisation approach has similarities with programme-based regional development which started in Finland in 1994. The regional development work was based on bottom-up processes relying on a broad partnership of regional actors but also on coordination by the State, for instance through the budgets of regional state offices (Virkkala, 2002). The strength of the Finnish system is its good connections between triple helix actors and high levels of investment in private and public RDI compared to some other EU countries (Reid and Maroulis, 2017). The weakness of the economy is a too centralised network structure based on a narrowly defined export base. The need for diversification with the help of smart specialisation was obvious after the crisis in ICT and the forestry industry at the time of launching the S3 (Mariussen et al., 2014). Finland has no national S3, although some national-level policies have similarities with S3 principles (Reid and Maroulis, 2017; Rinkinen, 2015). The S3 process was conducted at regional level by regional councils. Some regions embedded S3 in their regional development plans while others prepared a separate S3 document (Nissinen, 2017), an example being the regional council of Lapland (Teräs and Mäenpää, 2016) to support the smart transformation of the economy. Many regions developed new planning methods and approaches to S3. This chapter describes two methods developed as action research by Finnish researchers and used in the framework for entrepreneurial discovery: a connectivity tool and a regional development platform. Both are based on ideas on the promotion of interactive collective learning among stakeholders.

\section{Connectivity tool: Knowledge space and discovery through gap analysis}

The aim of the connectivity model developed by Virkkala et al. (2017) is to create a knowledge space for discovery to create social and cognitive proximities among stakeholders. This model consists of a survey that maps the structures of the networks that make up 
relations between various stakeholders, including gaps measured as tensions between expectations and experiences. The model is based on the idea that the driver of change in a relationship between two actors is the tension between expectations, which may be confirmed and strengthened, or frustrated. The gap between the values of expectations and experiences is used as an input in a structured dialogue in focus groups in which companies, universities, and public administration (or entrepreneurial actors) participate. Discussions on such gaps can improve the connectivity between stakeholders, and they can open the door to the discovery of emergent connections (weak relations that may be strengthened) and structural holes (lack of relations), which may reveal an opportunity for EDPs in the region as entrepreneurial actors resolve the issues hindering cooperation on various aspects of innovation. Gap analysis helps stakeholders to identify problems and set the parameters of the dialogues set up to resolve them. They can be used in constructing a shared vision and pooling scattered resources, but also in detecting the need for policy interventions, for example the alignment of educational, research and innovation policies in line with the regional strategy. Such usage adds experimental learning and gradual improvements to S3.

The model can be seen as one tool to assist EDP and collective knowledge creation. The SECI model by Nonaka and Takeuchi (1995) can be used as an analytical framework for understanding how mutual expectations or connectivity can be created. According to the SECI model, organisational and spatial proximity enables the creation of four stages of knowledge conversion. Below the relation between these stages and the connectivity model is explained (Table 8. 3).

In the stage of socialisation, tacit knowledge is created and shared between individuals mainly through face-to-face communication in a specific place $(b a)$. This open communication relies upon a certain level of mutual trust and openness, in short, social proximity. Through externalisation, tacit knowledge is articulated in the form of metaphors and diagrams so it might be understood by others: this is knowledge conversion. In the connectivity model, a researcher is asking about the tacit knowledge of the relationship; here, the expectations and experiences will be codified, and their distance will represent the gap index. This creates cognitive proximity, a shared and codified analysis of the situation in the relation, the achievements and challenges.

During the combination stage, explicit knowledge is then connected with existing knowledge through sorting, adding, systemising and categorising. Here, a shared theory or model of the problem at hand is developed, and new organisational solutions are suggested. In a connectivity model, this phase corresponds to a focus group meeting with the relevant stakeholders, who look for the explanation of the gap. Sometimes causal explanations are needed and sometimes more theoretical ones; this fosters discussion of the challenges discovered through the gap analysis. The aim of such discussion is to reach a consensus on the reasons for the relevant gap, as well as on possible policy interventions. A focus group meeting is $b a$, that is, time and space, which is shared in order to encourage the emerging relationships among individuals and groups, leading to the creation of knowledge. In the fourth stage, explicit knowledge is internalised and converted into practice, when individuals apply the new knowledge. Internalisation is closely related to learning by doing and processes of institutional transformation, as the relations change and new practices are developed. In the connectivity model, public actors should make decisions and prepare policy interventions. The implementation of the policy bridging the gaps needs to be internalised by the actors. The 
tacit knowledge accumulated at the individual level is in turn shared with others through socialisation, setting off a new spiral of knowledge creation.

The connectivity model aims to create knowledge improving the connectivity in the actor network and this knowledge corresponds to the organisational knowledge of the SECI process. The intention is to build a learning organisation incorporating the key regional stakeholders, and then use the SECI framework to organise the knowledge creation processes and to build higher levels of connectivity. In the focus group meetings, the reasons for the distance between partners are discussed, mental models are shared and strategies for knowledge bases are agreed upon.

Table 8.3 Phases of the SECI model and of the connectivity model

\begin{tabular}{|c|c|c|c|}
\hline SECI model & $\begin{array}{l}\text { Explanation of the } \\
\text { phases }\end{array}$ & Connectivity model & $\begin{array}{l}\text { Proximities and spaces in } \\
\text { connectivity model }\end{array}$ \\
\hline Socialisation & $\begin{array}{l}\text { Sharing tacit } \\
\text { knowledge }\end{array}$ & $\begin{array}{l}\text { Expectation and experience } \\
\text { in relations (as tacit } \\
\text { knowledge) }\end{array}$ & Social proximity \\
\hline Externalisation & $\begin{array}{l}\text { Articulation of tacit } \\
\text { knowledge: } \\
\text { metaphors, } \\
\text { diagrams, models, } \\
\text { prototypes, } \\
\text { explicating tacit } \\
\text { knowledge }\end{array}$ & $\begin{array}{l}\text { Codifying the gaps between } \\
\text { expectations and experiences } \\
\text { (e.g. on a } 1-10 \text { scale) }\end{array}$ & $\begin{array}{l}\text { A codified analysis of the } \\
\text { relation, gap index } \\
\text { Cognitive proximity }\end{array}$ \\
\hline Combination & $\begin{array}{l}\text { Connecting newly } \\
\text { created explicit } \\
\text { knowledge with } \\
\text { existing knowledge }\end{array}$ & $\begin{array}{l}\text { Focus group meeting, } \\
\text { Explanation of the gaps } \\
\text { through structured dialogue } \\
\text { Preparation of policy } \\
\text { interventions }\end{array}$ & $\begin{array}{l}\text { Knowledge space }(b a) \\
\text { encouraging emergent } \\
\text { relationships } \\
\text { Organisational proximity }\end{array}$ \\
\hline Internalisation & $\begin{array}{l}\text { Internalising new } \\
\text { explicit knowledge } \\
\text { and organisational } \\
\text { solutions in practice } \\
\text { by individuals }\end{array}$ & $\begin{array}{l}\text { Policy interventions } \\
\text { influence actors and their } \\
\text { relations }\end{array}$ & $\begin{array}{l}\text { Improved proximity } \\
\text { between actors }\end{array}$ \\
\hline Socialisation & $\begin{array}{l}\text { Sharing new } \\
\text { knowledge with } \\
\text { others } \\
\text { Setting off a new } \\
\text { spiral of knowledge } \\
\text { creation }\end{array}$ & $\begin{array}{l}\text { New relations and improved } \\
\text { proximity influence }\end{array}$ & $\begin{array}{l}\text { Better connectivity in the } \\
\text { network }\end{array}$ \\
\hline
\end{tabular}

In Ostrobothnia, the connectivity tool has been used among stakeholders of the main export cluster since 2014. The regional council has organised focus group meetings based on the findings of gap analysis every second year. Those focus group meetings have been structured dialogues on possible reasons for the biggest gaps. For instance, the companies in the energy sector reported that they do not get enough support from their local universities. There were also large differences in the expectations and experiences of companies and their regional 
subcontractors and the high expectations of the quality of production were mentioned. The gaps were analysed by origin and consequences, and policy interventions were planned by the regional council (Virkkala et al., 2017; 2014).

\section{Regional development platform (RDP): a space for discovering future clusters}

The concept of a platform is one used in many contexts, like that of the S3 platform guiding the regions or research platforms supporting interdisciplinary research. The concept of a platform can also refer to an innovation platform, a space to facilitate co-creation, which enables various actors to participate in innovation processes (Kautonen et al., 2017). In this chapter, the concept is used to explain how knowledge creation might be broadened based on existing clusters. It is important to bring together different but complementary pieces of knowledge, as well as the different technological domains which should be cross-fertilised. Knowledge creation through cross-fertilisation can happen on platforms, which can then be considered knowledge spaces.

The regional development platform (RDP) method was developed by Harmaakorpi (2006) and colleagues and tested in the Lahti region of Finland. The method describes the business potential in the region by offering promising combinations of industries, areas of expertise and future megatrends. The RDP method is a way of creating new paths from existing resource configurations. It describes the potential to form future regional clusters from the existing resource base. The actors of an RDP are the firms, technology centres, expertise centres, research centres, educational institutions, et cetera that define a development platform, and the process engages the actors in the discussion. The RDP consists of different phases like the analysis of the features of regional industries and their areas of expertise, expert panels and the assessment of future scenarios, the definition of potential development platforms, conceptualising the regional system, the search for the core processes of the regional innovation system and the definition of the management system (Harmaakorpi, 2006). Areas of expertise are formed by skills, capabilities and competencies assessed to be important independent of industry. It is a question of GPTs but also of other skills and competencies such as design.

Experts have a broad overview of the business life in the region, and they can verify the validity of the views of participants, and possibly update them in terms of agreed megatrends (Cooke, 2007). Megatrends should be reflected in the resource base of the regional innovation system in order to create new paths conferring regional competitive advantage. This phase should be effectuated as a result of interaction between the main actors of a region using futures research methods, such as the Delphi method. The process might increase the regional visionary capability of the participants (Harmaakorpi and Uotila, 2006). The potential development platforms in the region will be defined based on promising combinations of industries and areas of expertise. When the platforms have been identified, the core processes should be defined. Those core processes will aim to exploit the potential within the development platforms and enhance a region's dynamic capabilities. The core processes can also include some phenomena or future megatrends with the potential to bring business opportunities for the companies in the region. The knowledge creation and management approach used in the RDP method is based on the SECI and ba models, and the model created includes the learning spiral with tacit/explicit knowledge conversions and examples of $b a$ 
where the knowledge conversion takes place. The collective regional search process is also the EDP.

The regional development strategy work in the Lahti region is based on the RDP method and core process thinking (Harmaakorpi, 2006; Melkas and Uotila, 2013). Expert panellists from different fields evaluated the current situation of the industries, as well as the areas of expertise and the conditions they would offer for regional development. The panels were given four tables, each with two dimensions: grading each industry and area of expertise from 1-10 according to the various criteria, for instance the growth potential, innovativeness, and regional adequacy of educational opportunities. The different areas of expertise were also assessed. Expertise in this study was defined as expertise independent of the various industries, which is thus necessary for many industries. One of the new clusters which was founded as a cross-fertilisation of existing areas of expertise and industries and defined as platform was the Cleantech cluster that specialises in waste management and recycling, and water and soil management (Melkas and Uotila, 2013).

Table 8.4 compares the two tools for discovery developed for the EDP in Finland. Both use the SECI model as a framework to obtain tacit knowledge either from gaps in regional innovation networks (connectivity analysis) or from hidden resource configurations evaluated by expert panels.

Table 8.4 Comparison of the RDP method and the connectivity model

\begin{tabular}{|c|c|c|}
\hline & $\begin{array}{l}\text { Regional Development Platform } \\
\text { (RDP) Method (Lahti region) }\end{array}$ & $\begin{array}{l}\text { Connectivity model (Region of } \\
\text { Ostrobothnia) }\end{array}$ \\
\hline $\begin{array}{l}\text { Aim and } \\
\text { EDP role }\end{array}$ & $\begin{array}{l}\text { New growth trajectories } \\
\text { combining existing industrial } \\
\text { knowledge } \\
\text { Cross-sectoral variety creation } \\
\text { Discovery strategy }\end{array}$ & $\begin{array}{l}\text { Identification and bridging } \\
\text { relevant gaps and structural holes } \\
\text { in innovation system } \\
\text { Discovery strategy }\end{array}$ \\
\hline Main concept & $\begin{array}{l}\text { Related variety } \\
\text { Megatrends }\end{array}$ & $\begin{array}{l}\text { Gaps between experience and } \\
\text { expectation in relations in } \\
\text { innovation system }\end{array}$ \\
\hline Actors & $\begin{array}{l}\text { External experts, main } \\
\text { stakeholders }\end{array}$ & $\begin{array}{l}\text { Main stakeholders, can be within } \\
\text { the cluster }\end{array}$ \\
\hline $\begin{array}{l}\text { Proximities between } \\
\text { actors }\end{array}$ & Combining proximity and distance & $\begin{array}{l}\text { Creation of social and temporary } \\
\text { organisational proximity }\end{array}$ \\
\hline Problems & $\begin{array}{l}\text { Connecting different economic } \\
\text { activities and actors }\end{array}$ & $\begin{array}{l}\text { Too cluster oriented } \\
\text { From gaps to discovery }\end{array}$ \\
\hline Time horizon & Future-oriented, megatrends & $\begin{array}{l}\text { Present: gaps between } \\
\text { expectations and experiences }\end{array}$ \\
\hline Epistemic object & Future scenarios and technologies & $\begin{array}{l}\text { Gaps are expectations to be } \\
\text { fulfilled }\end{array}$ \\
\hline Knowledge space (Ba) & $\begin{array}{l}\text { RDP seminars with stakeholders, } \\
\text { expert seminars }\end{array}$ & $\begin{array}{l}\text { Focus group meetings among } \\
\text { stakeholders }\end{array}$ \\
\hline
\end{tabular}

Source: Own elaboration 
While the RDP method emphasises variety creation, the connectivity model aims to improve connectivity between entrepreneurial actors and influence the proximities between them by bridging the existing gaps in the innovation system. Such gaps should be viewed as full of expectations, and as containing the seeds of something new, a possible new domain

Both focus group meetings and RDPs can be interpreted as knowledge spaces aiming to connect different entrepreneurial actors, and which can be constructed by the agents in the discovery process. These agents are drawn from different helices (business, academia, or government) or communities of practice like the cluster or industry, and it is a challenge for a regional developer to dismantle the borders of communities of practice. To foster connectivity, some degree of cognitive proximity is needed so that people can learn from each other and collaborate successfully, and other dimensions of proximity such as the social, institutional, and organisational forms may facilitate that (Virkkala et al., 2017).

\section{Discussion and conclusions}

The current chapter approaches the mystery of discovery by examining the EDP as a knowledge creation process. It has posed a question regarding the connection between the creation of knowledge and the knowledge space in the context of the EDP. The chapter contributes to the emerging literature on smart specialisation, first by recognising the crucial role of tacit knowledge in discovery, which was possible owing to employing the SECI model describing how the tacit knowledge of individuals is converted so as to be shared with others, and with the aid of ideas around communities of practice, according to which knowledge is embedded in the action and knowledge sharing must be translated.

The second contribution of the chapter is to add the concept of knowledge space in conceptualising the EDP as a knowledge process. The knowledge space will be created simultaneously with knowledge. This argument is based on the reasoning of Nonaka and Takeuchi (1995) that learning is knowledge creation and its context is $b a$, which is the place where knowledge is created. The chapter developed the concept of knowledge space with the help of the notion of relational space explaining that space is constructed by the actors and the relationships between them. Knowledge space is a place in which knowledge from different sources and scales is combined, converted and translated. The concept of knowledge space is an abstract notion that has various features in the different phases of the EDP. The knowledge space emerges as relational space when the relations between entrepreneurial actors are changing.

Knowledge sharing might occur spontaneously between the actors, but in the deliberate search for ways to transform a regional economy, places for interaction of actors and interpretation of knowledge as well as searching and visioning should be organised. Knowledge space can be an organised RDP, a focus group meeting or a meeting place of local actors.

The current chapter developed a framework of EDP as knowledge creation process based on the SECI model, communities of practice and the notion of relational space, in which

- Tacit knowledge is embodied in the practice of entrepreneurial actors, often drawn from different communities of practices. 
- Entrepreneurial actors should be mobilised and connected in a knowledge space where they can interact and translate knowledge.

- Entrepreneurial actors reflect the knowledge communicated by others in a cognitive space in which interpretation is important. Individual and collective mental models are important to the interpretation of knowledge. Discovery is a process of applying sense and meaning to the knowledge.

- The new knowledge created and shared by the entrepreneurial actors can be combined with existing knowledge like the knowledge of general purpose technologies.

- The discovered new domain can be seen as a knowledge space. During implementation, new activities and firms will be launched using the knowledge created during discovery.

- Since the EDP is a continuous process, the knowledge space is also changing; it is a relational space that is in the process of becoming (see Figure 8.1

\begin{tabular}{|l|l|}
\hline $\begin{array}{l}\text { Domain consists of the } \\
\text { knowledge of the search process } \\
\text { and how it should be } \\
\text { implemented and subject to } \\
\text { experiment }\end{array}$ \\
\hline $\begin{array}{l}\text { Combination of new knowledge } \\
\text { refers to knowledge created in } \\
\text { interaction by entrepreneurial } \\
\text { actors with existing knowledge } \\
\text { like GPTs. }\end{array}$ \\
\hline $\begin{array}{l}\text { Entrepreneurial actors create } \\
\text { knowledge spaces across } \\
\text { borders between communities } \\
\text { of practice through interaction } \\
\text { (both of the virtual form and in } \\
\text { meeting places) and } \\
\text { interpretation, leading to } \\
\text { discoveries. These spaces can } \\
\text { be designed. }\end{array}$ \\
\hline $\begin{array}{l}\text { Communities of practice refer to } \\
\text { the context of specialised forms } \\
\text { of knowledge }\end{array}$
\end{tabular}

Figure 8.1 EDP as a process of creating knowledge and knowledge space. Source: own elaboration 
The chapter presented and compared two approaches developed by Finnish researchers for the design of knowledge space in the context of the EDP. The first being the focus group meeting organised around the gaps in the knowledge or the expectations of the stakeholders, as used in the region of Ostrobothnia. The second being the RDP method built around future expertise, as used in the Lahti region. Both methods use designed knowledge spaces that can be designed as tangible places of interaction, and which can result in a new knowledge space constructed by the actors involved. This new knowledge space can be at the core of the new domain.

The framework does have its issues: first, the discovery as a knowledge creation process depends on the regional institutional context of the emerging domain. Many authors (Morgan, 2017; Rodríguez-Pose and Wilkie, 2017) emphasise the role of sound institutions in enabling the EDP. The design of knowledge space has no meaning if the entrepreneurial actors are not motivated to share their knowledge. However, even in the less-developed regions with weak connectivity between the entrepreneurial actors and an environment that discourages cooperation and experimentation, it is possible to improve connectivity through structured discussions (see Chapter 3 by Blažek and Morgan (2019)).

The second issue arises from the inward-looking perspective of the framework. The sources and channels and combinations of knowledge are affected by globalisation and the digitalisation of the economy. It might not be enough to engage only regional entrepreneurial actors. Exploration requires combinatorial knowledge dynamics and extra-regional sources of knowledge (Sotarauta, 2017). To respond to this challenge, knowledge spaces should stretch to wider regions. One possibility is to construct knowledge space as transregional and transnational soft spaces like the new thematic partnership initiative by the EU; see Chapter 11 by Mariussen et al. (2019).

\section{References}

Amin, A. and Cohendet, P. (2004). Architectures of knowledge. Firms, capabilities, and communities. Oxford: Oxford University Press.

Bathelt, H. and Glückler, J. (2011). The relational economy. Geographies of knowing and learning. Oxford: Oxford University Press.

Bathelt, H., Malmberg, A. and Maskell, P. (2004). Clusters and knowledge: local buzz, global pipelines and the process of knowledge creation. Progress in Human Geography, 28 (1), pp. 31-56.

Blažek, J. and Morgan, K. (2019). The institutional worlds of entrepreneurial discovery. Finding a place for less developed regions. In Mariussen, Å., Virkkala, S., Finne, H. and Aasen, T. M. (eds.) The entrepreneurial discovery process and regional development. New knowledge emergence, conversion and exploitation. Abingdon: Routledge.

Boschma, R. (2005). Proximity and innovation: A critical assessment. Regional Studies, 39 (1), pp. 61-74.

Boschma, R. (2017). Regional diversification and smart specialisation policy. In McCann, P., van Oort, F. and Goddard, J. (eds.) The empirical and institutional dimensions of smart specialisation, pp. 23-38. London: Routledge.

Castells, M. (1998). The rise of the network society. Oxford: Wiley-Blackwell.

Cooke, P. (2007). To construct regional advantage from innovation systems first build policy platforms. European Planning Studies, 15 (2), pp. 179-194.

Cresswell, T. (2013). Geographical thought: A critical introduction. Chichester: Wiley-Blackwell. 
Foray, D. (2015). Smart specialisation. Opportunities and challenges for regional innovation policy. London: Routledge.

Foray, D. (2016). On the policy space of smart specialization strategies. European Planning Studies, 24 (8), pp. 1428-1437.

Frenken, K., Van Oort, F. and Verburg, T. (2007). Related variety, unrelated variety and regional economic growth. Regional Studies, 41 (5), pp. 685-697.

Harmaakorpi, V. (2006). Regional development platform method (RDPM) as a tool for regional innovation policy. European Planning Studies, 14 (8), pp. 1085-1104.

Harmaakorpi, V. and Uotila, T. (2006). Building regional visionary capability. Futures research in resource based regional development Technological Forecasting and Social Change, 73 (7), pp. 778-792.

Hautala, J. and Jauhiainen, J. S. (2014). Spatio-temporal processes of knowledge creation. Research Policy, 43 (4), pp. 655-668.

Ibert, O. (2007). Towards a geography of knowledge creation: The ambivalences between 'knowledge as an object' and 'knowing in practice'. Regional Studies, 41 (1), pp. 103-114.

Kautonen, M., Pugh, R. and Raunio, M. (2017). Transformation of regional innovation policies: from 'traditional' to 'next generation' models of incubation. European Planning Studies, 25 (4), pp. 620-637.

Lam, A. (2019). Career mobility, hybridity and knowledge combination. A 'third space' perspective. In Mariussen, A., Virkkala, S., Finne, H. and Aasen, T. M. (eds.) The entrepreneurial discovery process and regional development. New knowledge emergence, conversion and exploitation. Abingdon: Routledge.

Lave, J. and Wenger, E. (1991). Situated learning: Legitimate peripheral participation. Cambridge: Cambridge University Press.

Mariussen, Å. (2013). Sociological preliminaries: the societal context of transnational learning. In Mariussen, Å. and Virkkala, S. (eds.) Learning transnational learning, pp. 13-50. Abingdon: Routledge.

Mariussen, Å., Johnson, J. and Virkkala, S. (2014). Towards a smart specialisation strategy in Ostrobothnia and Finland. In Virkkala, S., Mäenpää, A. and Mariussen, $\AA$. (eds.) The Ostrobothnian model of smart specialisation, pp. 133-145. Vaasa: University of Vaasa.

Mariussen, Å., Hegyi, F. B. and Rakhmatullin, R. (2019). Smart specialisation. Interregional learning via thematic partnerships. In Mariussen, Å., Virkkala, S., Finne, H. and Aasen, T. M. (eds.) The entrepreneurial discovery process and regional development. New knowledge emergence, conversion and exploitation. Abingdon: Routledge.

Massey, D. (2005). For space. Los Angeles: Sage.

Melkas, H. and Uotila, T. (2013). Foresight and innovation: Emergence and resilience of the cleantech cluster at Lahti, Finland. In Cooke, P. (ed.) Re-framing regional development, pp. 203-233. London: Routledge.

Morgan, K. (2017). Speaking truth to power: The political dynamics of public sector innovation. In Kyriakou, D., Martínez, M. P., Periáñez-Forte, I. and Rainoldi, A. (eds.) Governing smart specialisation, pp. 49-61. London: Routledge.

Nissinen, M. (2017). Smart specialisation entering the Finnish territory. In Kyriakou, D., Martínez, M. P., Periáñez-Forte, I. and Rainoldi, A. (eds.) Governing smart specialisation, pp. 179-200. London: Routledge.

Nonaka, I. and Konno, N. (1998). The concept of "Ba": Building a foundation for knowledge creation. California Management Review, 40 (3), pp. 40-54.

Nonaka, I., Konno, N. and Toyama, R. (2001). Emergence of "Ba": A conceptual framework for the continuous and self-transcending process of knowledge creation. In Nonaka, I. and Nishiguchi, T. (eds.) Knowledge emergence: Social, technical and evolutionary dimensions of knowledge creation, pp. 13-29. Oxford: Oxford University Press.

Nonaka, I. and Takeuchi, H. (1995). The knowledge-creating company. How Japanese companies create the dynamics of innovation. New York NY: Oxford University Press. 
Nonaka, I. and Toyama, R. (2003). The knowledge-creating theory revisited: knowledge creation as a synthesizing process. Knowledge Management Research \& Practice, 1 (1), pp. 2-10.

Nonaka, I., Toyama, R. and Konno, N. (2000). SECI, ba and leadership: a unified model of dynamic knowledge creation. Long Range Planning, 33 (1), pp. 5-34.

Orlikowski, W. J. (2002). Knowing in practice: Enacting a collective capability in distributed organizing. Organization Science, 13 (3), pp. 249-273.

Paasi, A. (2002). Place and region: regional worlds and words. Progress in Human Geography, 26 (6), pp. 802-811.

Pred, A. (1984). Place as historically contingent process: Structuration and the time-geography of becoming places. Annals of the Association of American Geographers, 74 (2), pp. 279-297.

Reid, A. and Maroulis, N. (2017). From strategy to implementation: The real challenge for smart specialization policy. In Radosevic, S., Curaj, A., Gheorghiu, R., Andreescu, L. and Wade, I. (eds.) Advances in the theory and practice of smart specialization, pp. 294-319. London: Academic Press.

Rinkinen, S. (2015). Smart regional innovation policies - from cluster approaches to place-based policies. International Journal of Innovation and Regional Development, 6 (2), pp. 204-218.

Rodríguez-Pose, A. and Wilkie, C. (2017). Institutions and the entrepreneurial discovery process for smart specialization. In Kyriakou, D., Martínez, M. P., Periáñez-Forte, I. and Rainoldi, A. (eds.) Governing smart specialisation, pp. 34-48. London: Routledge.

Sotarauta, M. (2017). An actor-centric bottom-up view of institutions: Combinatorial knowledge dynamics through the eyes of institutional entrepreneurs and institutional navigators. Environment and Planning C: Government and Policy, 35 (4), pp. 584-599.

Teräs, J. and Mäenpää, A. (2016). Smart specialisation implementation processes in the north: Lessons learned from two Finnish regions. European Structural and Investment Funds Journal, 4 (2), pp. 75-86.

Tsoukas, H. (2003). Do we really understand tacit knowledge? In Easterby-Smith, M. and Lyles, M. A. (eds.) The Blackwell handbook of organizational learning and knowledge management, pp. 410-427. Malden MA: Blackwell Publishing.

Virkkala, S. (2002). The Finnish cases. Combining "top-down" and "bottom-up" partnership formation. In Östhol, A. and Svensson, B. (eds.) Partnership responses - Regional governance in the Nordic states, pp. 135-202. Stockholm: Nordregio.

Virkkala, S. and Mariussen, $\AA$. (2013). Theory of organizational knowledge creation as a framework for transnational learning in regional development. In Mariussen, $\AA$. and Virkkala, S. (eds.) Learning transnational learning, pp. 102-137. Abingdon: Routledge.

Virkkala, S. and Mariussen, $\AA$. (2019a). Emergence of new business areas in regional economies through entrepreneurial discovery processes. In Mariussen, Å., Virkkala, S., Finne, H. and Aasen, T. M. (eds.) The entrepreneurial discovery process and regional development. New knowledge emergence, conversion and exploitation. Abingdon: Routledge.

Virkkala, S. and Mariussen, Å. (2019b). Self-discovery enabling entrepreneurial discovery processes. In Mariussen, Å., Virkkala, S., Finne, H. and Aasen, T. M. (eds.) The entrepreneurial discovery process and regional development. New knowledge emergence, conversion and exploitation. Abingdon: Routledge.

Virkkala, S., Mäenpää, A. and Mariussen, À. (eds.) (2014). The Ostrobothnian model of smart specialisation. Vaasa: University of Vaasa.

Virkkala, S., Mäenpää, A. and Mariussen, Å. (2017). A connectivity model as a potential tool for smart specialization strategies. European Planning Studies, 25 (4), pp. 661-679.

Vissers, G. and Dankbaar, B. (2013). Knowledge and proximity. European Planning Studies, 21 (5), pp. 700-721.

Weick, K. E. (2001). Making sense of the organization. Malden MA: Blackwell.

Wenger, E. (1998). Communities of practice. Learning, meaning, and identity. Cambridge: Cambridge University Press. 


\section{Notes}

i The Japanese word $b a$ translates into English as place.

ii SECI is an acronym of the words Socialisation, Externalisation, Combination and Internalisation.

iii ICT can be used for instance in modernising tourism, nanotechnology in the forest industry when developing new materials to supplement plastics; biotechnology is important in the modern fishing industry. 3D printing can be used in the medical industry for producing new human parts or in the automotive industry to produce components, for instance. 